\title{
Anal imperforation in a Congo village: a challenge for treatment
}

\author{
Mariana Capela 지 , Joana Reis, Raquel Guedes
}

Pediatric and Neonatologie Department, CHVNG/E, Vila Nova de Gaia, Portugal

\section{Correspondence to} Dr Mariana Capela; marianacarvalhocapela@gmail. com

Accepted 13 January 2021

\section{DESCRIPTION}

Most anorectal malformations are identified in the examination of the newborn or are manifested in the first 24 hours by abdominal distension, absence of dejections and bilious vomiting. ${ }^{1}$ The type of surgery is variable, but immediate evaluation is urgent to avoid serious complications such as intestinal perforation and sepsis. ${ }^{23}$ We report a case of a male newborn, transported by plane on the third day of life from a rural area to a level II hospital in Kinshasa, due to anal imperforation noted at birth, with bilious vomiting in the first 24 hours of life. On examination, he showed signs of moderate dehydration, abdominal distention and absence of anal orifice (figure 1). Meconium emission through the urinary meatus was observed, with no visible fistulas. A nasogastric tube was placed immediately to decompress the abdomen and prevent intestinal perforation. The analytical study was normal and abdominal ultrasound revealed anorectal malformation with a suspected urinary fistula. He was submitted to surgery with terminal colostomy and

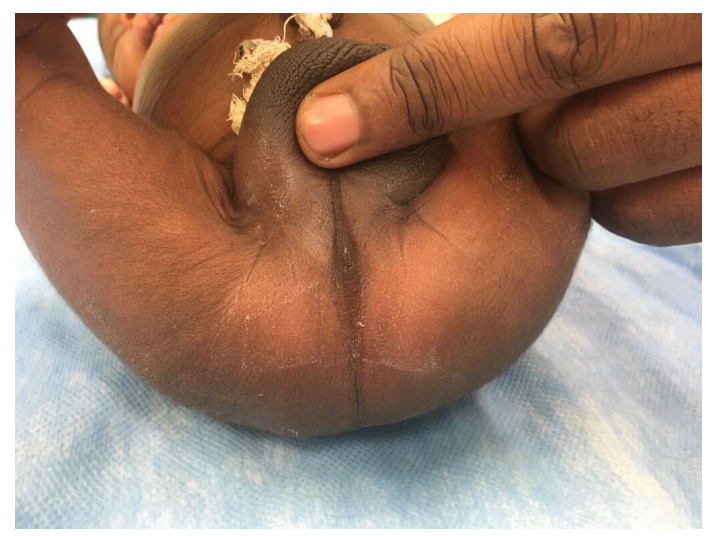

Figure 1 Anal imperforation on examination.

\section{Learning points}

- This case highlights the importance of early diagnosis of a malformation whose diagnosis is clinical and easy to perform.

- Surgical intervention, fluid therapy and antibiotics are essential in the treatment, but they are not always available, which made this case a real challenge.

started antibiotherapy with cefotaxime. He had a fever in the first day after surgery, so metronidazole and amikacin were added. He started breastfeeding with good tolerance, with progressive reduction in fluid therapy. He was discharged after 7 days with reconstructive surgery already scheduled.

Acknowledgements We would like to thank Dr Valentin Kazadi, who performed the surgery and helped us in this case.

Contributors MC, JR and RG were the main authors of this case report.

Funding The authors have not declared a specific grant for this research from any funding agency in the public, commercial or not-for-profit sectors.

Competing interests None declared.

Patient consent for publication Parental/guardian consent obtained.

Provenance and peer review Not commissioned; externally peer reviewed.

\section{ORCID iD}

Mariana Capela http://orcid.org/0000-0002-2793-7851

\section{REFERENCES}

1 Santos ERet al. Imperforate anus: litetrature review. Rev Med Minas Gerais 2012;22:S71-5

2 Pakarinen MP, Rintala RJ. Management and outcome of low anorectal malformations. Pediatr Surg Int 2010;26:1057-63.

3 Rintala RJ. Congenital anorectal malformations: anything new? J Pediatr Gastroenterol Nutr 2009;48:579-82.

Copyright 2021 BMJ Publishing Group. All rights reserved. For permission to reuse any of this content visit https://www.bmj.com/company/products-services/rights-and-licensing/permissions/

BMJ Case Report Fellows may re-use this article for personal use and teaching without any further permission.

Become a Fellow of BMJ Case Reports today and you can:

- Submit as many cases as you like

- Enjoy fast sympathetic peer review and rapid publication of accepted articles

- Access all the published articles

- Re-use any of the published material for personal use and teaching without further permission

Customer Service

If you have any further queries about your subscription, please contact our customer services team on +44 (0) 2071111105 or via email at support@bmj.com.

Visit casereports.bmj.com for more articles like this and to become a Fellow 